\title{
Sequence-based Bacteriological Probing of Domestic Water Sources in Kiagbodo, Delta State, Nigeria
}

\author{
T Sampson ${ }^{1 *}$ and KBD Yom ${ }^{2}$ \\ ${ }^{1}$ Department of Microbiology, Rivers State University, Nkpolu-Oroworukwo, Port \\ Harcourt, Nigeria \\ ${ }^{2}$ Department of Biological Science, Edwin Clark University, Kiagbodo, Delta State, \\ Nigeria \\ *Corresponding Author: T Sampson, Department of Microbiology, Rivers State \\ University, Nkpolu-Oroworukwo, Port Harcourt, Nigeria.
}

Received: April 06, 2021

Published: May 07, 2021

(C) All rights are reserved by $\mathbf{T}$ Sampson and KBD Yom.

\begin{abstract}
Major sources of drinking water originates from underground water which is then made accessible through boreholes and mono pumps. However, the portability of drinking water across the globe has increasingly continued to be in doubt, due to the problem of microbial contamination, prompting the need for water quality assessments in areas where boreholes and mono pumps are major sources of drinking water. Thus, this study was carried out to assess the bacteriological quality of domestic water sources in Kiagbodo, Delta State, Nigeria. Water samples used for domestic purposes were obtained from three different boreholes (labelled BH1, BH2, and BH3) and three different mono pumps (tagged MP1, MP2, and MP3) and then assessed for their total heterotrophic bacterial count (THBC) as well sequencing the bacterial isolates, using the sanger method, for their genomic identities. Results from the study showed that mono pumps had the greater counts of heterotrophic bacteria with a mean $\log _{10}$ THBC of 4.55 as against, 3.25 mean $\log _{10}$ THBC counts observed across borehole samples. There was a statistical difference in the bacterial counts between the mono pumps and borehole samples $(\mathrm{p}<0.05)$. The total heterotrophic bacteria counts (THBC) observed across all six water samples (boreholes and mono pumps) ranged from $5.0 \times 10^{2}$ to $2.83 \times 10^{5} \mathrm{cfu} / \mathrm{ml}$, which were all well above the permissible THBC standard limit recommended by WHO and FAO $\left(1.2 \times 10^{2} \mathrm{cfu} / \mathrm{ml}\right)$ and the CDC $\left(<5 \times 10^{2} \mathrm{cfu} / \mathrm{ml}\right)$. Molecular identification of the bacterial species isolated from the domestic water sources (boreholes and monopumps) revealed the presence of four different genus of bacteria to include Bacillus, Proteus, Staphylococcus and Chryseobacteria. The identified species were Bacillus thuringiensis, Proteus vulgaris, Staphylococcus aureus and Chryseobacterium cucumeris. The sources of domestic water in this community were therefore, observed to be well contaminated, containing large amount of heterotrophic bacteria, thus threatens the health of individuals exposed to these water sources. Treatment of these water sources is therefore recommended to check possible outbreak of waterborne diseases in this locality.
\end{abstract}

Keywords: Bacteriological Probing; Water Quality; Domestic; Sequencing; Kiagbodo

\section{Introduction}

Water quality is simply refers to the suitability of water for use, as determined by certain parameters such as chemical and biological. Water supply and accessibility is goal 6 of the sustainable development goals (SDGs) and aims at ensuring environmental sustainability [1]. Water safety and accessibility to quality water is being given much attention, historically [2] and in recent time, due to the increasing cases of water quality associated outbreaks. Assessing the role of community based water sources as reservoirs for organisms capable of causing waterborne diseases is not only critical for disease surveillance and notification purposes but also to enlighten the individuals in these localities on need for water purification before use for various purposes.

Most developing Nations, including Nigeria, are faced with the problem of poor water quality, as portable water supply is in most cases limited to urban settlements. Globally, more than 1.2 billion people lack access to safe water [3] due to problem of hygiene and in part as a result of dearth of water treatment facilities. The problem of water quality is not only limited to the burden of waterborne 
illnesses like cholera, dysentery and other diarrheal diseases but also affects industrial processes as well as food processing in localities, as almost all industrial processes require water devoid of microbial contamination.

Water is susceptible to contamination with microorganisms and organic matter among other pollutants regardless of the source [4]. Microbial groups such as Escherichia coli, Cryptosporidium parvum, and Giardia lambia are frequent contaminants that influence the quality and safety of water. Indicator organisms such as Escherichia coli, Klebsiella, and Enterobacter species in water determines the microbiological quality of water, as these organisms are reporters of the possible presence of pathogenic organisms such as Clostridium pafringens, Salmonella, and Protozoan parasites. These pathogens cause diarrhea, giardiasis, dysentery, and gastroenteritis, which is common among the rural dwellers of developing nations [5].

Groundwater represents the world's largest and most important source of fresh potable water and one abstract of groundwater is boreholes. Groundwater is generally considered a "safe source" of drinking water because it is abstracted with low microbial load with little need for treatment before drinking. However, groundwater resources are commonly vulnerable to pollution, which may degrade their quality. Main sources of pollution of wells and boreholes are industrial, domestic, and agricultural, such pollution. The sources of pollution can however be of natural origin or of an anthropogenic source. Microorganisms of public health concerns are those associated with various health challenges like diarrhoea and gastroenteritis and include Salmonella spp., Shigella spp., Escherichia coli, Vibrio cholerae, Entamoeba histolytica, Giardia lamblia, etc. these organisms cause serious human health issues when found on water sources.

Quality of water determination is therefore important to assess the suitability of a particular water source for domestic and other uses. The parameters that define water quality include physical, chemical, and biological parameters. The biological parameters involve living organisms, including microorganisms (bacteria, viruses, fungi) present in water bodies which can contribute to the quality of water. Different methods are available for the determination of the microbiological quality of water. Traditional methods include the analysis for the presence of indicator microorganisms [6]. Sequence-based molecular technique has however, been used in recent time $[7,8]$ as a throughput methodology to identify and characterize pathogens from various samples including drink- ing water sources [9]. There is however paucity of data regarding the bacteriological quality of water used for domestic purposes in Kiagbodo, a rural community in Delta State, Nigeria. Results from this study involving molecular tools are however, needed as important and reliable sets of data for public health policy formulation, as well as aiding epidemiologists in deciphering the bacterial community dynamics influencing rural domestic water quality and disease outbreak.

\section{Aim of the Study}

The aim of the study was therefore to determine the bacteriological quality of water used for domestic purposes in Kiagbodo, Delta State, Nigeria, using a culture dependent molecular technique.

\section{Materials and Methods \\ Collection of water samples}

The samples were collected from six (6) different points (in triplicates) at Kiagbodo (Burutu LGA), Delta State, namely: Poubolor (tap water), Amatolo (tap water), Gbale (tap water), Dibeye (mono pump), Kpabiri (mono pump) and Atimagbene (mono pump). Sterile bottles were used in collecting the water from tap water and mono pumps in the six (6) different sample points. The samples were covered tightly to prevent further contamination and refrigerated at $4^{\circ} \mathrm{C}$ prior to analysis.

\section{Bacteriological analysis}

The water samples were taken through the process of serial tenfold dilution and subsequently inoculated $(0.1 \mathrm{ml})$ onto freshly prepared nutrient agar and MacConkey agar plates before incubating for 24 hours at $37^{\circ} \mathrm{C}$. After incubation, colonies were counted and pure cultures were obtained by sub-culturing distinct colonies on fresh agar plates using the streak plate method. This was done using a sterile wire loop, the inoculum was then deposited on a plate containing a fresh media and was streaked up and down the surface of the media. The media was then incubated for 24 - 48 hours. Bacterial isolates were identified on the basis of colonial characteristics and their reaction to biochemical tests such as catalase, motility, oxidase, coagulase, methyl red, Voges Proskaeur, citrate utilization, sugar fermentation and urease tests as described by Cheesbrough, 2005 [10].

\section{Molecular characterization}

\section{DNA extraction (Boiling method)}

Five millilitres of an overnight broth culture of the bacterial isolate in Luria Bertani (LB) were spun at 14000 rpm for 3 minutes. 
The cells were re-suspended in 500 ul of normal saline and heated at $95^{\circ} \mathrm{C}$ for 20 minutes. The heated bacterial suspension was cooled on ice and spun for 3 minutes at $14000 \mathrm{rpm}$. The supernatant containing the DNA was transferred to a $1.5 \mathrm{ml}$ microcentrifuge tube and stored at $-20^{\circ} \mathrm{C}$ for other downstream reactions.

\section{DNA quantification}

The extracted genomic DNA was quantified using the VIS Nanodrop 1000 Spectrophotometer. The software of the equipment was lunched by double clicking on the Nanodrop icon. The equipment was initialized with $2 \mu \mathrm{l}$ of sterile distilled water and blanked using normal saline. Two microliter of the extracted DNA was loaded onto the lower pedestal, the upper pedestal was brought down to contact the extracted DNA on the lower pedestal. The DNA concentration was measured by clicking on the "measure" button.

\section{S rRNA amplification}

The 16S rRNA region of the rRNA gene of the isolates were amplified using the 27F: 5'-AGAGTTTGATCMTGGCTCAG-3' and 1492R: 5'-CGGTTACCTTGTTACGACTT-3' primers on an ABI 9700 Applied Biosystems thermal cycler (Plate 3.2) at a final volume of 40 microliters for 35 cycles. The PCR mix included: The X2 Dream taq Master mix supplied by Inqaba, South Africa (taq polymerase, DNTPs, $\mathrm{MgCl}$ ), the primers at a concentration of $0.5 \mu \mathrm{M}$ and the extracted DNA as template. The PCR conditions were as follows: Initial denaturation, $95^{\circ} \mathrm{C}$ for 5 minutes; denaturation, $95^{\circ} \mathrm{C}$ for 30 seconds; annealing, $52^{\circ} \mathrm{C}$ for 30 seconds; extension, $72^{\circ} \mathrm{C}$ for 30 seconds for 35 cycles and final extension, $72^{\circ} \mathrm{C}$ for 5 minutes. The product was resolved on a $1 \%$ agarose gel at $130 \mathrm{~V}$ for 30 minutes and visualized on a blue light transilluminator.

Sequencing

Sequencing analysis was performed at Inqaba Biotechnical Pty Ltd, South Africa. This was done using a BigDye Terminator kit on a $3510 \mathrm{ABI}$ sequencer maintained at a final volume of $10 \mu \mathrm{l}$. The components included $0.25 \mu$ Big Dye ${ }^{\circledR}$ terminator v1.1/v3.1, 2.25 ul of $5 \mathrm{x}$ Big Dye sequencing buffer, $10 \mu \mathrm{M}$, Primer PCR primer, and 2-10 ng PCR template per $100 \mathrm{bp}$. The sequencing conditions involved 32 cycles of $96^{\circ} \mathrm{C}$ for $10 \mathrm{~s}, 55^{\circ} \mathrm{C}$ for $5 \mathrm{~s}$ and $60^{\circ} \mathrm{C}$ for $4 \mathrm{~min}$.

\section{Results}

The results as shown in table 1 reveal the total heterotrophic bacteria counts $(\mathrm{cfu} / \mathrm{ml})$ of water samples from the six sampled

\begin{tabular}{|c|c|c|}
\hline Sample ID & THBC $-\mathbf{c f u} / \mathbf{m l}$ & $\mathbf{L O G}_{\mathbf{1 0}}$ THBC \\
\hline Borehole & & \\
\hline BH 1 & $5.0 \pm 0.10 \times 10^{2}$ & 2.70 \\
\hline BH 2 & $2.5 \pm 0.05 \times 10^{3}$ & 3.40 \\
\hline BH 3 & $4.4 \pm 0.01 \times 10^{3}$ & 3.64 \\
\hline \multicolumn{2}{|c|}{ Mean LOG $\mathbf{T H B C}$} & 3.25 \\
\hline Mono pump & & \\
\hline MP 1 & $2.0 \pm 0.10 \times 10^{4}$ & 4.30 \\
\hline MP 2 & $8.0 \pm 0.02 \times 10^{3}$ & 3.90 \\
\hline MP 3 & $2.83 \pm 0.07 \times 10^{5}$ & 5.45 \\
\hline Mean LOG 10 & 4.55 \\
\hline
\end{tabular}

Table 1: Total heterotrophic bacterial counts THBC $(\mathrm{cfu} / \mathrm{ml})$.

Key: BH: Borehole/Tap Water; MP: Mono Pump Water.

locations. Mono-pump samples had a greater count of Total Heterotrophic Bacterial Count (THBC) than borehole samples. The result revealed that the mean $\log _{10}$ Total Heterotrophic Bacterial Count (THBC) across boreholes and mono-pump samples was 3.25 and 4.55 respectively. The borehole sample having the highest value for Total Heterotrophic Bacteria was BH 3 with THBC of $4.4 \pm 0.01 \mathrm{x}$ $10^{3} \mathrm{cfu} / \mathrm{ml}$ and $\log _{10}$ THBC of 3.64, while for mono-pump samples, the result revealed that MP3 had the highest Total Heterotrophic Bacterial Count of $2.83 \pm 0.07 \times 10^{5}$ and $\log _{10}$ THBC of 5.45 .

Results of the $1 \%$ agarose gel electrophoresis for the visualization of the 16s rRNA region of the rRNA gene of the isolates showed that the amplified PCR products possessed a molecular weight that each corresponded to 1500 base pairs. The purified lanes labelled B1-B4 shown in plate 1 represent the 16s rRNA gene bands $(1500$ bp), while lane $\mathrm{L}$ represents the 100 base pair (bp) molecular ladder.

The obtained 16S rRNA sequence from the isolate produced an exact match during the megablast search for highly similar sequences from the NCBI non-redundant nucleotide (nr/nt) database. The evolutionary distances computed using the Jukes-Cantor method were in agreement with the phylogenetic placement of the $16 \mathrm{~S}$ rRNA of the isolates P3, T1, T4 and T2 within the Bacillus, Proteus, Staphylococcus and Chryseobacterium genera and revealed a closely relatedness to Bacillus thuringiensis, Proteus vulgaris, Staphylococcus aureus and Chryseobacterium cucumeris respectively (Figure 1). 


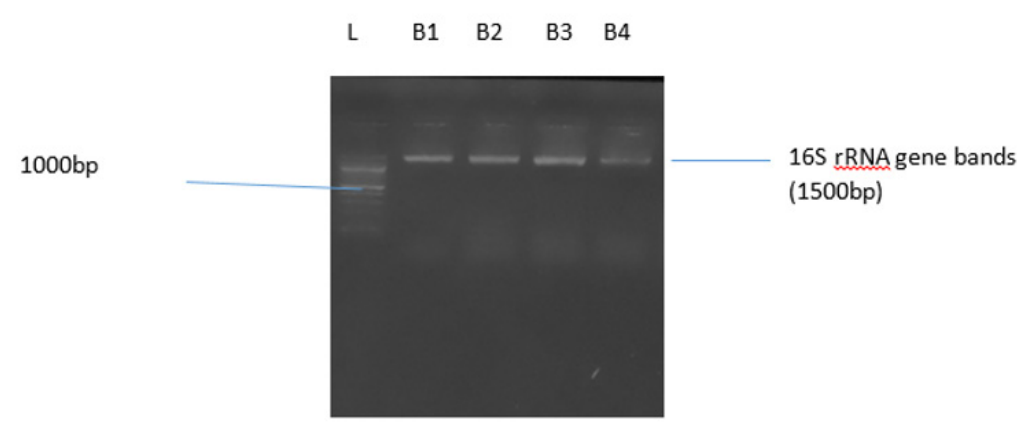

Plate 1: Agarose gel electrophoresis of the 16S rRNA gene of some selected bacterial isolates.

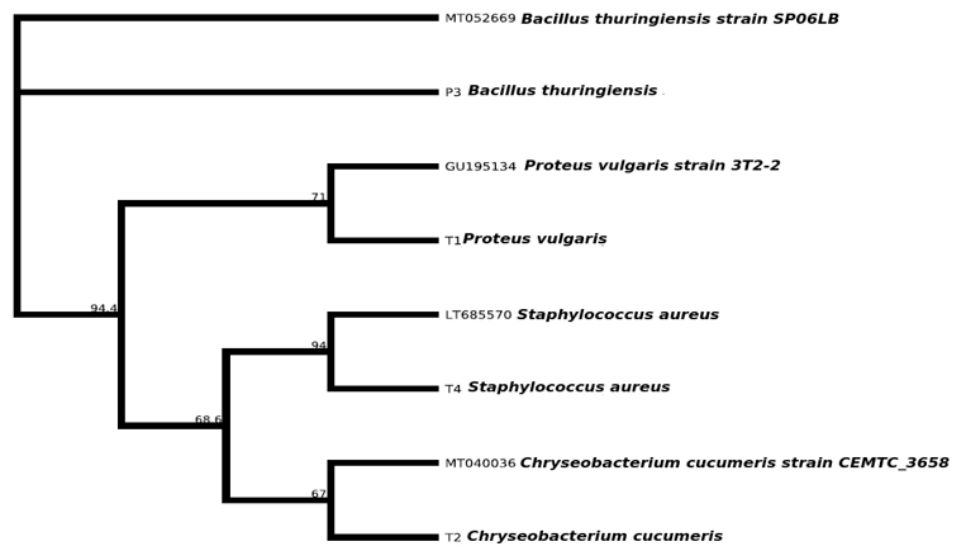

Figure 1: Phylogenetic profiling of the bacterial isolates.

On the basis of visual observation, the 16S rRNA region of each DNA sample (boreholes and monopumps samples) used was seen aligning themselves at 1500 base pairs ( $1500 \mathrm{bp}$ ) which proves the presence of bacterial species in the water samples corresponding with the previous research that bacteria are about 1500 base pairs long.

\section{Discussion}

The results from the present study showed that mono-pump samples had greater counts of Total Heterotrophic Bacteria (THB) than borehole samples. This shows that there is higher population and variety of bacteria in mono-pumps than in boreholes, implying that the risk of waterborne diseases is higher in mono pumps than borehole. It follows that while the borehole water was distributed from an overhead storage tank exposed to the effect of tempera- ture and solar radiation, water from the mono-pump was collected in situ from the underground source with less exposure to the effect of temperature and solar radiation.

The effect of storage on the bacteriological properties of underground water has been reported by earlier researchers [11]. The erratic nature of piped water supply has made water storage a common practice among individuals and households, especially in areas where there is pressure on available water source. Maggy., et al. (2003) [11] indicated that the duration of storage affected the microbiological quality of stored ground water. Similarly, Olayemi., et al. (2005) [12] and Eniola., et al. (2006) [13] highlighted the importance of a few days of indoor storage in improving the physical and microbiological quality of water. In many communities in Nigeria, it is common to pump ground water into overhead storage-tanks. The most common household reservoirs are plastic tanks, usually of dif- 
ferent colours, placed outdoor. The outdoor location of the water tanks exposes them to solar radiation. In addition to generating heat, many forms of radiations are harmful to microorganisms. Low levels of ionizing radiations will produce mutations and may indirectly result in death, whereas higher levels are directly lethal. Even visible light, when present in sufficient intensity can damage or kill microbial cells [14].

Total Heterotrophic Bacterial Count (THBC) in each of the analyzed samples was found to be above the acceptable standard of total heterotrophic bacteria count in a potable water as recommended by the Centres for Disease Control and Prevention [15]. The Centres for Disease Control and Prevention stated that heterotrophic plate count levels in potable water should be $<500 \mathrm{CFU} /$ $\mathrm{ml}$. However, that these levels may increase on occasion, but counts consistently $>500 \mathrm{CFU} / \mathrm{mL}$ would indicate a general decrease in water quality [15]. Therefore, putting the standard given by CDC into consideration, it would be seen that there are far greater count of heterotrophic bacteria in the studied water samples (both boreholes and mono-pumps). The Total Heterotrophic Bacterial Count (THBC) among borehole samples was highest in BH3 with THBC of $4.4 \pm 0.01 \times 10^{3} \mathrm{cfu} / \mathrm{ml}$ (approximately $4400 \mathrm{cfu} / \mathrm{ml}$ ). THBC was lowest in BH1, $5.0 \pm 0.10 \times 10^{2} \mathrm{cfu} / \mathrm{ml}(\sim 500 \mathrm{cfu} / \mathrm{ml})$ which appears to fall within the value given by $\mathrm{CDC}(<500 \mathrm{cfu} / \mathrm{ml})$. Among mono pumps samples, MP3 had a greater count of heterotrophic bacteria with a THBC of $2.83 \pm 0.07 \times 10^{5} \mathrm{cfu} / \mathrm{ml}(\sim 283000 \mathrm{cfu} /$ $\mathrm{ml}$ ), while the mono pump sample with the lowest heterotrophic bacteria count was MP2, $8.0 \pm 0.02 \times 10^{3} \mathrm{cfu} / \mathrm{ml}(\sim 8000 \mathrm{cfu} / \mathrm{ml})$ These results are well above the standard count of heterotrophic bacteria given by CDC and can therefore indicate that the water is not of good quality.

Results from previous studies $[16,17]$ collaborates with the results obtained in this study. Rogbesan., et al. (2002) [17] reported heavy bacterial load in water from some boreholes in Ilorin, $\mathrm{Ni}$ geria. While Ibiene., et al. (2012) [16] carried out a study on the bacteriological assessment of drinking water sources in Opuraja Community of Delta State, Nigeria, and reported that all the water sources fell far below the standards approved by WHO and NAFDAC due to the observed total heterotrophic count ranging from $1.45 \times 10^{3}$ to $1.5 \times 10^{6}$ for all sources of water. This therefore shows that the bacteriological quality of water varies depending on the source and location. This variation may be influenced by both physicochemical, biological as well as metrological dynamics [18].
The importance of molecular characterisation of bacterial communities in an environment has been highlighted by earlier reports $[7,18,19]$. From the molecular analysis in this study, the identified bacterial species were Bacillus thuringiensis, Proteus vulgaris, Staphylococcus aureus and Chryseobacterium cucumeris. The bacterial genera identified in this study have also been identified by previous studies $[8,20,21]$ to be frequent contaminants of water sources. Niyi-David., et al. (2020) [8] in a molecular study on bacterial isolates from fish ponds identified Chryseobacterium cucumeris as part of the bacterial population in pond water. The study by Eniola., et al. (2007) [21] implicated Proteus vulgaris and Staphylococcus aureus to be among the bacterial contaminants that influenced the quality of borehole water in storage tanks. A similar study conducted by Onuorah., et al. (2019) [20] showed that P. vulgaris (46.7\%) and $S$. aureus $(13.3 \%)$ were among the prevalent bacterial species in borehole water in Ogbaru Communities, Anambra State, Nigeria. While some of these previous studies $[20,21]$ were based on phenotypic identification, this present research on the sequence-based bacteriological probing of domestic water sources in Kaigbodo, Delta State, presents a more reliable and throughput approach and confirms the findings of earlier researchers on microbial quality of domestic water sources in a rural setting.

Some of these bacterial contaminants like Staphylococcus and Bacillus are well characterized frequent contaminants of different environments like toilet seats [22], water, soil, etc. and pose serious human health challenges, necessitating public health intervention measures. S. aureus in domestic water may also serve as a source for colonizing residents exposed to these contaminated water sources. Several studies have found no evidence of any clinical syndrome associated with exposure to some of these species like Bacillus thuringiensis. However, some products with Bacillus thuringiensis have caused eye and skin irritation [23]. Bacteria from the genus Proteus are well known as human opportunistic pathogens and common causes of bladder, kidney and other body infections. They are also known as intestinal microorganisms indicating fecal pollution of water or soil. Their presence in drinking water poses a threat of infection and poisoning when the contaminated water or food is consumed. Chryseobacterium infections are uncommon. These microorganisms are common pathogens of plants and animals but infrequently cause human infections [24].

\section{Conclusion and Recommendations}

The study has been able to probe the bacteriological quality of water used for domestic purposes in Kiagbodo, Delta state. It has 
revealed that the domestic water sources (boreholes and mono pumps) in Kiagbodo, Delta State, Nigeria, are not of a good quality due to the far greater population of bacteria in the studied water samples. The higher bacterial population in mono pumps than in boreholes suggests that water from boreholes could actually be safer than mono pumps. The isolation of Proteus vulgaris and Staphylococcus aureus in this study is an indication that an outbreak could occur in the near future if these domestic water sources are not checked and treated.

The local authorities as well as governmental agencies should set out regulations to control human activities done near domestic water sources to check the proliferation of pathogenic group of microorganisms. Proper treatment such as chlorination of domestic water sources is advised in order to check microbial activities. Also, the use of metagenomics as a non-culture dependent approach is recommended in this study to decipher the community dynamics of bacterial genera influencing the domestic water quality in this locality.

\section{Competing Interests}

The authors declare that they have no competing interests.

\section{Bibliography}

1. Akoteyon I S. "Hydrochemical Studies of Groundwater in Parts of Lagos. Southwestern Nigeria”. Bulletin of Geograohy, Physical Geography 6 (2013): 27-42.

2. Todd DK and Mays LW. "Groundwater Hydrology". $3^{\text {rd }}$ edition. John Wiley and Sons Inc (2005).

3. WHO (World Health Organisation). "Guidelines for Drinking Water Quality". Health Criteria and Other Supporting In-formation. $2^{\text {nd }}$ Edition. World Health Organisation Press, Geneva 2 (1996).

4. Kumar M., et al. "A comparative evaluation of groundwater suitability for irrigation and drinking purposes in two intensively cultivated districts of Punjab. India". Environmental Geology 53 (2007): 553-574.

5. Phillips AJ., et al. "Engineered applications of ureolytic biomineralization: a review”. Biofouling 29.6 (2013): 715-733.

6. Briancesco T. "Bacteriological characteristics of water". International Journal of Environmental Research 3 (2005): 395405.
7. Sampson T., et al. "Molecular Characterization and Detection of Antibiotic Resistance Genes in Pseudomonas Species Isolated from Tympanotonusfuscatus". Journal of Advances in Microbiology 20.6 (2020): 37-45.

8. Niyi-David CC., et al. "Molecular Characterization of Isolates and Antibiotic Resistance Genes Associated with Fish Pond". International Journal of Research and Innovation in Applied Science (IJRIAS) 5.8 (2020): 11-16.

9. Olowe B M., et al. "Molecular Identification of Escherichia coli and New Emerging Enteropathogen, Escherichia fergusonii, From Drinking Water Sources in Ado-Ekiti, Ekiti State, Nigeria”. Journal of Microbiology Research 7.3 (2017): 45-54.

10. Cheesbrough M. "District Laboratory Practice in Tropical Countries". Cambridge University Press, United Kingdom (2005): 30-41.

11. Maggy N., et al. "Operational Paper: The Microbiological quality of groundwater derived drinking water after long storage in household containers in a rural community of South Africa". Journal Water SRT- Aqua 52 (2003): 67-77.

12. Olayemi AB., et al. "Effect of Storage on Bacteriological Quality of Borehole Water". African Journal of Clinical and Experimental Microbiology 6.3 (2005): 213-218.

13. Eniola KIT., et al. "Effect of Storage on Bacteriological Quality of Well Water". African Journal of Clinical and Experimental Microbiology 7.1 (2006): 27-32.

14. Prescott LM., et al. "Water. Microbiology". (4th edition). McGraw-Hill Co. Inc., New York (1999): 876-882.

15. CDC. Guidelines for Environmental Infection Control in Healthcare Facilities. Centers for Disease Control and Prevention (CDC) (2003).

16. Ibiene AA., et al. "Bacteriological Assessment of Drinking Water Sources in Opuraja Community of Delta State, Nigeria". Nature and Science 10.1 (2012).

17. Rogbesan AA., et al. "Bacteriological Examination of some Boreholes within University of Ilorin (PS)". Nigeria Journal of Pure and Applied Science 17 (2002): 1223-1226. 
18. Sampson T., et al. "Molecular and Antibiotic Susceptibility Profiling of Bacteria Isolated from Pre-sterilized Food Samples Used as Substrates for Outdoor Air Quality Assessment" (2020).

19. Sampson T., et al. "Determination of the Bacterial Community Structure in a Crude Oil inundated Tropical Soil Using Next Generation Sequencing Technique". Journal of Advances in Microbiology 11.1 (2018): 1-18.

20. Onuorah S., et al. "Bacteriological Assessment of the Public hand-pump borehole water in Onueke, Ezza South Local Government Area, Ebonyi State, Nigeria". International Journal of Photochemistry and Photobiology 2.2 (2019): 39-48.

21. Eniola K I T., et al. "Effects of Containers and Storage Conditions on Bacteriological Quality of Borehole Water". Nature and Science 5.4 (2007): 1-6.

22. Sampson T., et al. "Bacteriological Assessment of Toilet Seats in a Nigerian University". Journal of Advances in Microbiology 19.4 (2019): 1-11.

23. National Pesticide Information Center. Bacillus thuringiensis (Bt). National Pesticide Information Center (NPIC) (2019).

24. Vandamme P., et al. "Notes: new perspectives in the classification of the Flavobacteria: Description of Chryseobacterium gen. nov., Bergeyella gen. nov., and Empedobacter nom. Rev". International Journal of Systematic and Evolutionary Microbiology 44 (1994): 827-831.

\section{Volume 4 Issue 6 June 2021}

(c) All rights are reserved by T Sampson and KBD Yom. 